\title{
Relationship between Coping Strategies, Bullying Behaviors and Nursing Students' Self Esteem
}

\author{
Fadi Abdalrazak Albakoor, Lecturer \\ Health Education in Nursing, Faculty of Nursing, Tishreen University-Syrian Arab \\ Republic
}

\author{
Mervat Moustafa El-Gueneidy, Professor \\ Psychiatric Nursing and Mental Health, Faculty of Nursing, Alexandria University, Egypt \\ Omneya Mohamed El-Fouly, Lecturer \\ Nursing Education, Faculty of Nursing, Alexandria University, Egypt
}

\begin{abstract}
Bullying has probably existed in schools for centuries. It is one of the most difficult and prevalent problems that schools face, in spite of the fact that all students have the right to have education in a safe environment. Bullying is a significant issue confronting the nursing profession, with victims described as being part of an oppressed group. Objective: Explore types of bullying experienced by Faculty of Nursing students, Alexandria University during clinical training. Setting: The current study was conducted at the Faculty of Nursing-Alexandria University. Subjects: 754 male and female nursing students. Tools: Bullying in Nursing Education Questionnaire, Rosenberg SelfEsteem Scale, and Brief Challenging Outdoor Personal Experience (COPE) Inventory. Results: The findings of this study revealed that $51.9 \%$ of nursing students are experiencing bullying behaviors. Male students reported more frequently bullying behaviors rather than female students. . The majority of students reported low level of experienced bullying behaviors. The majority of students chose not to report bullying behaviors because they reported that nothing would be done anyway. And as a response to forms of bullying behavior "Negative or disparaging remarks about becoming nurse" was the most frequently reported. As regarding source of bullying behaviors the most frequent source of bullying behavior are clinical instructors. Conclusion: Bullying clearly exists in nursing education and is likely to continue unless nurse educators recognize the problem and agree to do something about it. Recommendations: Clinical instructors must be able to supply helpful feed-back, evaluate student performance for building on nursing knowledge and skill, and recognize students' efforts.
\end{abstract}

Keywords: Bullying behaviors; Coping Strategies; Self Esteem.

\section{Introduction}

Bullying in nursing has existed for decades and appears to be a growing concern as nurse retention and recruitment become crucial factors in sustaining health care system. The phenomenon of bullying in nursing existed for decades in nursing and in clinical settings ${ }^{(1)}$. Orpinas \& Horne (2006) stress that bullying is probably one of the most difficult and prevalent problems that nursing schools face today, while all students have the right to have education in a safe environment ${ }^{(2)}$. Bullying refers to "situations in which a person repeatedly and eventually feels subjected to negative treatment on the part of one or more persons, and the person exposed to the treatment has difficulty in defending himself against these actions $^{(3)}$. Acts of bullying have been referred to as horizontal violence, relational aggression, incivility, mobbing, harassment, and interpersonal conflict. Regardless of the label, all terms encompass negative and unwanted acts toward others ${ }^{(4)}$. Celik and Bayraktar (2004) studied the incidence of verbal, physical, sexual, and academic abuse experienced by nursing students in Turkey. Verbal abuse was the most frequently reported type of abuse, followed in order by academic, sexual, and physical abuse. All participants reported being yelled at, being 
behaved toward in an inappropriate, nasty, rude, or hostile way, they have also been belittled or humiliated. All participants identified their classmates as a primary source of verbal abuse, followed by faculty members as the second frequent source. The effects of this abuse were anger, guilt, shame, helplessness, depression, and thoughts of leaving the nursing profession ${ }^{(5)}$.

Davey (2002) also reported that the process of nursing education often made students feel like they were being thrown to the wolves. This "sink or swim" approach creates a sense of vulnerability that quickly squelches any enthusiasm the student might have for nursing. Many students complain of being stripped of their dignity and pride, and they feel invisible and inferior. The students also experienced hostility, disrespect, and unfriendliness from peers and faculty alike, during the educational process ${ }^{(6)}$.

In Egypt (2015) study at Faculty of Nursing, Mansoura University the majority of nursing students at the faculty of nursing students were exposed to moderate degree of bullying than health institute nursing students. The most frequently reported behaviors by nursing students were yelling or shouting in rag as about one fourth of them are usually and always exposed to it. While, the majority of them were never exposed to cursing or swearing. Staff nurse and other hospital staff were the most frequent sources of bullying behaviors as perceived by both faculty and health institute nursing students while faculty and classmate were the lowest. On the other hand, clinical instructor was the most frequent sources of bullying behaviors as perceived by the faculty nursing students ${ }^{(7)}$.

Randle (2003) discovered that bullying was a universal theme known in students' reports and that reporting bullying was a routine experience in the progression of becoming a nurse. Also he stated that the way a student nurse was treated during training produced a student's process of becoming a nurse ${ }^{(7,8)}$.
Moreover nursing students have been identified as victims of aggression from patients and their families. It has also been found that they are more concerned about the aggression that occurs among their colleagues and other nurses ${ }^{(9,10)}$. Bullying has been shown to decrease self-confidence and work productivity. Moreover, it makes students feel frustrated leading to alteration in their performance and efficacy within the academic setting $^{(11)}$. Thus, McKenna et al (2003) stated that newly registered nurses reported feelings of diminished self-esteem and self confidence as a result of experiences of horizontal violence ${ }^{(12)}$.

A dual relationship exists between bullying behaviors and the person's self esteem. Self-esteem is concerned with an evaluation of one's self and refers to individuals' like or dislike of themselves ${ }^{(13)}$.

Self-esteem has been reported to be affected by experience in clinical setting. Randle (2001) emphasized that nursing students identified negative experiences associated with clinical placements, as they described being devalued and felt that nurses used the power associated with their position to undermine their self-esteem. Student nurses also reported witnessing nurses humiliate patients ${ }^{(14)}$.

When coping strategies and selfesteem were examined, a relationship was noted between students with low self-esteem and the use of self-blame as a method of coping with bullying behaviors ${ }^{(15)}$.

\section{Aims of the Study}

1. Explore types of bullying experienced by Faculty of Nursing students during clinical training.

2. Identify coping strategies used by Faculty of Nursing students to deal with such bullying.

\section{Research Questions}

1. What are the types of bullying experienced by Faculty of Nursing students during clinical training? 
2. What are the coping strategies used by Faculty of Nursing students to deal with such bullying?

\section{Materials and Method}

\section{Materials}

Design: A descriptive correlational research design was used to carry out this study.

Setting: The study was conducted at the Faculty of Nursing-Alexandria University.

Subjects: The study subjects were all nursing students enrolled in the six academic semesters in the above setting. The first and second semesters were excluded as students have limited contact with clinical areas and with persons at the faculty. A convenient sampling technique was used to choose the study subjects. The total number of nursing students who participated in the study was 754 male and female students.

Tools: Three tools were used:

\section{Tool I: The Bullying in Nursing Education Questionnaire}

It comprised 32 statements associated with the phenomenon of bullying, on which students were asked to indicate behavior frequency. Responses were measured on a 4point Likert rating scale ranging from (1) never to (4) all the time. The total score ranged from 32 to 128 . The higher the scores, the higher the experiences of bullying behaviors.

\section{Tool II: The Rosenberg Self-Esteem Scale}

It includes ten items answered on a four point Likert scale ranging from strongly agree (4) to strongly disagree (1). Five items of them were positive statements and the others were negative. Ones in case of negative statements, the scores were reversed. The total score was divided into 3 levels low, moderate, and high self esteem.

\section{Tool III: The Brief Challenging Outdoor Personal Experience (COPE) Inventory}

It consists of 14 subscales representing 14 separate coping mechanisms with 2 -items per scale, namely: self-distraction, active coping, denial, substance abuse, use of emotional support, use of instrumental support, behavioral disengagement, venting, positive reframing, planning, humor, acceptance, religion, and self-blame. Responses were measured on a 4-point Likert rating scale ranging from (1) not doing this at all to (4) doing this a lot. The total scores ranged from 28 to 112 . The higher the scores, the better the coping strategies used.

\section{Method}

The steps followed in the present study were:

\section{Administrative process:}

An official permission is obtained by submission of an official letter from the Faculty of Nursing to the responsible authorities of the study setting to obtain the authorization for data collection.

\section{Development and preparation of the study tools:}

Tool I, Tool II, and Tool III were translated into Arabic.

Validity of the tools: Tools were submitted to nine experts in the related fields to determine content validity .Reliability of the tools Reliability was done using testretest method on 50 nursing students from 3rd-8th semester at the Faculty of Nursing, Alexandria University who were selected randomly. Retesting was done after 30 days of collecting the pilot data. The test proved that tools were reliable.

\section{Pilot study:}

It was carried out on 50 nursing students. Those students were excluded from the actual study. The purpose of the pilot study was to ensure the clarity of items and their comprehension, applicability and relevance of the tools, in addition to identify obstacles and problems that may be occurring during data collection. Also, to estimate the time required to fill in the tool. Following to this 
pilot study, the tool was reconstructed and made ready for use.

\section{Actual field work:}

Data were collected during the second semester of the academic year 2015-2016 through two phases. In the first phase, tool I was used to identify students who experienced behavior on all students enrolled in the 3rd-8th semesters at Faculty of Nursing, Alexandria University those who return the sheet were 754. In the second phase, tools II and III were used with the students who reported experiencing bullying behaviors number amounted 391 .

\section{Ethical considerations:}

The aim of the study is explained to students before participation, and voluntary participation is emphasized and a written consent is obtained, and the confidentiality and anonymity of the subjects was assured through coding the data. Subjects were also assured that can they withdraw from the study at any time without any rational.

\section{Statistical Analysis}

The quantitative data were analyzed using Statistical Package for Social Sciences (SPSS) program version 20. Data were presented in tables and figures using actual numbers and percentages. Appropriate statistical methods were applied (percentage, chi-square, ANOVA, correlation coefficient (r), t-test. Regarding $\mathrm{p}$ value, it was considered that: non-significant if $\mathrm{p}>0.05$, significant if $\mathrm{p}<0.05$.

\section{Results}

Table (1) According to demographic and academic characteristics, the result reveals that the total number of nursing students was 754 , their age ranged from 20-25 years .The majority of students $(81.3 \%)$ were females, and $(95.9 \%)$ were single. Almost threequarters $(72.7 \%)$ of the nursing students were living in rural areas. In relation to study semesters an almost equal percentage (38.5\% and $38.3 \%$ ) were in the 3rd-4th and 5th-6th semesters respectively, while $23.2 \%$ were enrolled in the 7th-8th semesters. According to last GPA, it was found that $56 \%$ of the nursing students received (B) grade, $41.6 \%$ received (C) grade, and only $2.4 \%$ received (A) grade. In relation to experience of bullying behaviors, it was found that 391 represented $(51.9 \%)$ of the nursing students experienced bullying behaviors during their clinical training, distributed 81 male and 310 female.

Table (2) presents the distribution of nursing students according to their experience of bullying behaviors by study semester. It appears from this table that 391 representing $51.9 \%$ of the nursing students experienced bullying behaviors during their clinical training. Amount half of the nursing students in each semester experienced bullying behaviors $50.7 \%, 55.4 \%$, and $48 \%$ respectively. The highest percent of students exposed to bullying behaviors were enrolled in the fifth and sixth semesters (55.4\%).

Table (3) reveals the number of students who reported experiencing bullying behavior by sex. It appears that the number of nursing students with experience of bullying behavior amounted to 391 while the number of students who did not report bullying experiences were 363 . In relation to sex ,the total number of males were 141, among these 81 experienced bullying behavior representing $(57.4 \%)$, while the total number of females amounted to 613 among these $310(50.6 \%)$ experienced bullying behavior.

Table (4) shows the effects of bullying behaviors on nursing students. It appears from this table that 229 of the studied students thought of leaving nursing studies as a result of being bullied. These were distributed respectively according to study semesters. Those who thought of leaving nursing program because of bullying were $64.6 \%$ of bullied students in 3rd-4th , 50\% in 5th-6th, and $64.3 \%$ in 7 th-8th semester respectively .The rest 162 bullied students did not consider leaving the nursing program. Also this table illustrates that $63.9 \%$ of nursing students told someone 
about being exposed to bullying behaviors. In relation to the person being notified, the table shows that $39.6 \%$ reported to a staff nurse, $32.3 \%$ to a classmate, $23.8 \%$ to clinical instructors, $8.2 \%$ to physician, and only $2.3 \%$ to other hospital staff.

Table (5) shows the distribution of source of bullying behaviors as reported by studied nursing students. It appears that students stated the most frequent source of bullying behavior is clinical instructors as mentioned by $68.2 \%$ of all those experiencing bullying behavior, followed by Staff nurse $54.7 \%$, and classmate $53.7 \%$. The least frequent source of bullying was other hospital staff mentioned by114 students representing (29.1\%).

Table (6) shows that $(58.1 \%)$ of the students had moderate level and $16.1 \%$ had low level of self esteem. The level of self esteem was high among only $25.8 \%$ of bullied students. In relation to level of self esteem and studied semesters no significant difference was found in this respect.

Table (7) illustrates the relation between bullying behavior and coping strategies, used by studied students .This table shows that student nurses reported using religion as a coping strategy most frequently (47\%); followed by positive reframing coping (30.9\%), venting coping $(28.9 \%)$, and Planning coping (27.9\%). While, active coping and substance abuse were the least used coping strategies $(3.1 \%$, and $3.8 \%$ ), respectively.

Table (8) shows the correlation between bullying behaviors, coping Strategies, and self esteem, among bullied nursing students. As shown in the table, it was clear that no significant correlation was found between bullying behaviors, coping strategies, and self esteem.

\section{Discussion}

Bullying is a universal problem; there is vital need to understand bullying behaviors in nursing and nursing education. It is an increasing significant issue facing the nursing profession. Nurses are usually considered part of an apprised group. Bullying has an impact on the work place environment in nursing schools and on student nurses in general causing low morale in addition to a negative view of the profession. Bullying and harassment among nursing students and in healthcare facilities are recognized internationally and considered a problem that increases occupational stress, and staff nursing shortage $^{(16)}$.

When students nurse identify this problem and dealing with it this help students nurses wellbeing, better integration into the profession, increased satisfaction with nursing and reduce their tendency to leave the profession ${ }^{(17)}$. Bullying and its effect on self esteem are seen frequently in nursing education and practice. Nursing students are often subjected to bullying in their academic setups and clinical nursing practice.

This study was carried out at the Faculty of Nursing - Alexandria University and discussed the occurrence nature, severity, frequency and sources of bullying experienced by students doing their clinical training. The results show that around half of the studied nursing students experience bullying. This could be due to the societal trend toward tolerance for increasing levels of negative behaviors or even their fear and intimidation. In addition to that, all students are young, so they lack the suitable way to deal with bullying. These results are slightly lower than those found in previous studies involving nursing students. The present results are almost consistent with a Turkish and a U.K. study which found that half of their nursing students experience bullying behavior during nursing education ${ }^{(18)}$. On the other hand, an Egyptian study was conducted by Abd El Rahman (2013), at Faculty of Nursing, Damanhour University. The study revealed that up to $88 \%$ of the study subjects experienced bullying behaviors in the clinical setting ${ }^{(16)}$. In the same respect, Cooper et al. (2011), stated 
that, nursing students have the highest risk of experiencing negative behaviors because of being younger with less experienced, and lower less education, other reasons for these experiences are frequent ward changes and the challenge of meeting new environment $^{(19)}$.

As regards gender it was noted in the previous study that $57.4 \%$ of male students reported being victim of bullying behaviors, the figure for female students was a lit flower $(50.6 \%)$. This may be due to the community image of nurses being females and rejecting male nurses, female also found that they will lose their dignity and will feel shamed if they will report the bully behaviors. This is congruent with Sable et al. $(2006)^{(20)}$, who revealed that males were significantly more concerned about shame, guilt and embarrassment, issues surrounding confidentiality and fear of not being believed, which support society's prevailing attitude toward nursing. This may be also in part due to the fear of stigmatization that accompanies the reporting of victimization particularly by male students (Victims of Violence, 2008) ${ }^{(21)}$. This is supported by Bray (2001) who suggested that workplace gender segregation, which can be found in careers such as nursing, and nurse education, increases the frequency of same-sex bullying. Also he states that '...people tend to work with colleagues of their own gender, there is a tendency for women to bully women and men to bully men ${ }^{(22)}$.

The present study also revealed that around half of the studied bullied students considered leaving the nursing program. This may be due to the students' perception of themselves as an oppressed group that is affected by social view of nurses and being bullied adds to their negative self image of nursing. Moreover, being bullied by their instructors adds to their fear of being negatively appraised and not affable of being objectively evaluated. Similarly, studies investigating nursing students' intentions to leave nursing revealed that anywhere from $34 \%$ to nearly $70 \%$ of students who experienced bullying behaviors considered leaving the profession $^{(23)}$. Regarding the source of bullying behavior, the results of this study revealed that clinical instructors and staff nurses are the most frequent sources of bullying behaviors as perceived by nursing students. This may be related to the students' frequent contact with their teaching assistants and staff nurses in clinical settings where they spend long clinical hours. Also, staff nurses deal with nursing students as junior nurses and they give them orders to complete indirect activities such as sending and receiving lab investigation and transferring patient to radiology department. These results are consistent with those of Clarke et al. (2012), who identified that student nurses are experiencing and witnessing bullying behaviors at various frequencies, most notably by clinical instructors, who hold both authoritarian and evaluative position. Present result are consistent with Magnussen and Amundson (2003) who noted that respondents reported that some nursing instructors actually impede students educational experiences, undervalue them, or treat them in uncaring ways ${ }^{(24)}$. This finding consistent with $\mathrm{Abd} \mathrm{El}$ Rahman (2014) who reported that nursing faculty and clinical instructors are the most frequent perpetrators of bullying behaviors as perceived by the nursing students were the most frequent source of bullying.

In relation to level of student's selfesteem, the current study revealed that only a quarter of bullied students have low self esteem, this is supported by Basal and El hossiny (2014) who found that students who perceived bullying behaviors occasionally lose self confidence and out that it is possible for extreme self-consciousness to bear an impact on self-esteem. They add that the more self-conscious is the person, the less the degree of self-esteem ${ }^{(25)}$. This is congruent with present results revealing that Nursing students who self-labeled themselves as being bullied had lower selfesteem scores than those who labeled themselves as not having been bullied. Also 
The current study viewed that, the majority of nursing students have moderate selfesteem as $58.1 \%$ this is supported by a study in (2008) where the majority of nursing students have moderate level of self esteem in all academic years ${ }^{(26)}$.

As regards used coping strategies, current result show that students who perceived a greater amount of bullying, used emotion-focused coping to a greater degree, seeking emotional support as a mean of coping with bullying behaviors. Active coping strategies are usually applied when individuals believe that the stressful situation can be changed while passive strategies are used when individuals think nothing can be done to change the external threat or when they lose control over the situation (Lazarus \& Folkman, 1984) ${ }^{(27)}$. The coping strategy used thus depends on the perception of the stressor.

The present study has not shown significant associations between frequency of bullying and ways of coping. However, the most effective coping strategies may depend on the type of bullying experienced. Sharp (1995) investigated used coping strategy by students in response to being bullied, and found that most common by used were passive coping strategies such as ignoring the bully (73\% of responses) and walking away (70\%). Also other used assertive strategies such as standing up for themselves (68\%), and more than a quarter of the students (26\%) reported passively accepting the situation $^{(28)}$.

\section{Conclusion}

The findings of this study have implications for nursing students and nursing profession more broadly. So Universities must develop transparent policies and procedures to manage this critical problem. Results suggest that nursing students experience and witness bullying behaviors at various frequencies, most notably by clinical instructors and staff nurses at the six academic semesters. On the other hand, the majority of nursing students at faculty of nursing students had moderate level of self esteem. According to coping degree, it was noticed the studied students had low level of coping degree, at all semesters. Also, the findings of the study show that no significant correlation was found between bullying behaviors, coping strategies, and self-esteem.

\section{Recommendations}

- Nursing, faculty staff and students must be educated about bullying behavior and how to deal with it.

- Clinical instructors must be able to supply helpful feed-back, evaluate student performance for building on nursing knowledge and skill, and recognize students efforts

- Make students aware about the goals that need to be attained in their courses through effective communication on goal progress, and develop instructional programs that train students on the use of certain strategies to improve their performance modeling cognitive strategies.

- Students must be conscious of procedures for reporting experiences of bullying.

- Develop and implement curricula that educate nursing students on bullying behaviors, to eradicate this behavior. 
Table (1): Sociodemographic characteristics of the total enrolled nursing students

\begin{tabular}{|c|c|c|}
\hline $\begin{array}{l}\text { Demographic and educational } \\
\text { Characteristics }\end{array}$ & $\begin{array}{c}\text { No } \\
\mathrm{n}=754\end{array}$ & $\begin{array}{c}\% \\
100 \%\end{array}$ \\
\hline $\begin{array}{l}\text { Age of students } \\
<20 \\
20-22 \\
23-25 \\
>25 \\
\end{array}$ & $\begin{array}{c}37 \\
627 \\
88 \\
2 \\
\end{array}$ & $\begin{array}{c}4.9 \% \\
83.16 \% \\
11.67 \% \\
0.27 \% \\
\end{array}$ \\
\hline $\begin{array}{l}\text { Min - max } \\
\text { Mean } \pm \text { SD }\end{array}$ & \multicolumn{2}{|c|}{$\begin{array}{c}20-25 \\
21.08 \pm 1.17 \\
\end{array}$} \\
\hline $\begin{array}{l}\text { Gender } \\
\text { Male } \\
\text { Female }\end{array}$ & $\begin{array}{l}141 \\
613\end{array}$ & $\begin{array}{l}18.7 \% \\
81.3 \% \\
\end{array}$ \\
\hline $\begin{array}{l}\text { Residence } \\
\text { Urban } \\
\text { Rural }\end{array}$ & $\begin{array}{l}548 \\
206\end{array}$ & $\begin{array}{l}72.7 \% \\
27.3 \%\end{array}$ \\
\hline $\begin{array}{l}\text { Marital status } \\
\text { Single } \\
\text { Married }\end{array}$ & $\begin{array}{c}723 \\
31\end{array}$ & $\begin{array}{c}95.9 \% \\
4.1 \%\end{array}$ \\
\hline $\begin{array}{l}\text { Semesters } \\
\text { Third and Fourth } \\
\text { Fifth and Sixth } \\
\text { Seventh and Eighth }\end{array}$ & $\begin{array}{l}290 \\
289 \\
175 \\
\end{array}$ & $\begin{array}{l}38.5 \% \\
38.3 \% \\
23.2 \% \\
\end{array}$ \\
\hline $\begin{array}{l}\text { GPA } \\
\text { A } \\
\text { B } \\
\text { C } \\
\end{array}$ & $\begin{array}{c}18 \\
422 \\
314 \\
\end{array}$ & $\begin{array}{l}2.4 \% \\
56.0 \% \\
41.6 \% \\
\end{array}$ \\
\hline
\end{tabular}

Table (2): Distribution of all nursing students according to their experience of bullying behaviors

\begin{tabular}{|c|c|c|c|c|c|c|c|c|c|c|}
\hline \multirow{3}{*}{$\begin{array}{l}\text { Experience of Bullying } \\
\text { behaviors }\end{array}$} & \multicolumn{8}{|c|}{ Semesters } & \multirow{3}{*}{$\begin{array}{l}\text { Test of } \\
\text { Sig. }\end{array}$} & \multirow{3}{*}{$\mathbf{p}$} \\
\hline & \multicolumn{2}{|c|}{$\begin{array}{l}3^{\text {rd }}-4^{\text {th }} \\
n=290\end{array}$} & \multicolumn{2}{|c|}{$\begin{array}{l}5^{\text {th }}-6^{\text {th }} \\
n=289\end{array}$} & \multicolumn{2}{|c|}{$\begin{array}{l}7^{\text {th }}-8^{\text {th }} \\
n=175\end{array}$} & \multicolumn{2}{|c|}{$\begin{array}{c}\text { Total } \\
n=754\end{array}$} & & \\
\hline & No & $\%$ & No & $\%$ & No & $\%$ & No & $\%$ & & \\
\hline Experienced & 147 & $50.7 \%$ & 160 & $55.4 \%$ & 84 & $48.0 \%$ & 391 & $51.9 \%$ & & ค 260 \\
\hline Did not experienced & 143 & $49.3 \%$ & 129 & $44.6 \%$ & 91 & $52.0 \%$ & 363 & $48.1 \%$ & $\left.\right|^{x=2.024}$ & 0.209 \\
\hline
\end{tabular}

$\chi^{2}, p: \chi^{2}$ and $p$ values for Chi square test 
Table (3): Distribution of bullying behaviors reported by studied subjects by sex

\begin{tabular}{|c|c|c|c|c|}
\hline Gender & Male & Female & & otal \\
\hline Experience of Bullying & $\mathrm{N} \quad \%$ & $\mathbf{N}$ & $\mathbf{N}$ & $\%$ \\
\hline $\begin{array}{l}\text { Reported } \\
\text { Experience of Bullying }\end{array}$ & $81 \quad 57.4 \%$ & $310 \quad 50.6 \%$ & 391 & $51.9 \%$ \\
\hline $\begin{array}{l}\text { Not reported } \\
\text { Experience of Bullying }\end{array}$ & $60 \quad 42.6 \%$ & $30349.4 \%$ & 363 & $48.1 \%$ \\
\hline Total & $100 \%$ & $100 \%$ & 754 & $100 \%$ \\
\hline
\end{tabular}

Table (4): Effect of bullying behaviors on nursing students by academic semesters

\begin{tabular}{|c|c|c|c|c|c|c|c|c|}
\hline \multirow{5}{*}{$\begin{array}{l}\text { Effect of bullying behaviors } \\
\text { Leaving the nursing program: } \\
\text { Yes } \\
\text { No }\end{array}$} & \multicolumn{6}{|c|}{ Semesters } & \multirow{2}{*}{\multicolumn{2}{|c|}{$\begin{array}{c}\text { Total } \\
(\mathbf{N}=391)\end{array}$}} \\
\hline & \multicolumn{2}{|c|}{$3^{\text {rd }}-4^{\text {th }}$} & \multicolumn{2}{|c|}{$5^{\text {th }}-6^{\text {th }}$} & \multicolumn{2}{|c|}{$7^{\text {th }}-8^{\text {th }}$} & & \\
\hline & \multicolumn{2}{|c|}{$\mathrm{N}=147 \quad \%$} & \multicolumn{2}{|c|}{$\mathrm{N}=160 \%$} & \multicolumn{2}{|c|}{$\mathrm{N}=84 \quad \%$} & \multicolumn{2}{|c|}{$\mathrm{N} \%$} \\
\hline & 95 & $64 . \%$ & 80 & $50 \%$ & 54 & $64 . \%$ & 229 & $58.6 \%$ \\
\hline & 52 & $35 . \%$ & 80 & $50 \%$ & 30 & $35 . \%$ & 162 & $41.4 \%$ \\
\hline $\begin{array}{l}\text { Did you tell anyone if exposed to } \\
\text { bullying behaviors? } \\
\text { No } \\
\text { Yes }\end{array}$ & $\begin{array}{l}72 \\
75\end{array}$ & $\begin{array}{l}49 \% \\
51 \%\end{array}$ & $\begin{array}{l}61 \\
99 \\
\end{array}$ & $\begin{array}{l}38.1 \% \\
61.9 \%\end{array}$ & $\begin{array}{c}8 \\
76\end{array}$ & $\begin{array}{c}9.5 \% \\
90.5 \%\end{array}$ & $\begin{array}{l}141 \\
250\end{array}$ & $\begin{array}{l}36.1 \% \\
63.9 \%\end{array}$ \\
\hline \multirow{6}{*}{$\begin{array}{l}\text { If yes, who you told? } \mathbf{N = 2 5 0} \\
\text { - Staff nurse } \\
\text { - Clinical instructors } \\
\text { - Classmate } \\
\text { - Physician } \\
\text { - Other hospital staff }\end{array}$} & \multicolumn{2}{|c|}{$\mathrm{N}=75$} & \multicolumn{2}{|c|}{$\mathrm{N}=99$} & \multicolumn{2}{|c|}{$\mathrm{N}=76$} & \multicolumn{2}{|c|}{$\mathrm{N}=250$} \\
\hline & 46 & $31.3 \%$ & 67 & $41.9 \%$ & 42 & $50 \%$ & 155 & $39.6 \%$ \\
\hline & 26 & $17.7 \%$ & 36 & $22.5 \%$ & 31 & $36.9 \%$ & 93 & $23.8 \%$ \\
\hline & 46 & $31.3 \%$ & 46 & $28.7 \%$ & 34 & $40.8 \%$ & 126 & $32.3 \%$ \\
\hline & 17 & $11.7 \%$ & 6 & $3.7 \%$ & 9 & $10.7 \%$ & 32 & $8.2 \%$ \\
\hline & 0 & 0.0 & 3 & $1.9 \%$ & 6 & $7.1 \%$ & 9 & $2.3 \%$ \\
\hline
\end{tabular}

*More than one answer was provided 
Table (5): Sources of experienced bullying behaviors as reported by studied nursing students

\begin{tabular}{|c|c|c|c|c|c|c|c|c|}
\hline \multirow{3}{*}{ Sources of bullying } & \multicolumn{6}{|c|}{ Semesters } & \multirow{3}{*}{\multicolumn{2}{|c|}{$\begin{array}{c}\begin{array}{c}\text { Total } \\
(\mathrm{n}=391) \\
\text { No } \%\end{array}\end{array}$}} \\
\hline & \multicolumn{2}{|c|}{$\begin{array}{c}3^{\text {rd }}-4^{\text {th }} \\
(n=147)\end{array}$} & \multicolumn{2}{|c|}{$\begin{array}{c}5^{\text {th }}-6^{\text {th }} \\
(n=160)\end{array}$} & \multicolumn{2}{|c|}{$\begin{array}{c}7^{\text {th }}-8^{\text {th }} \\
(n=84)\end{array}$} & & \\
\hline & No. & $\%$ & No. & $\%$ & No. & $\%$ & & \\
\hline Staff nurse & 75 & $51.0 \%$ & 90 & $56.2 \%$ & 49 & $58.3 \%$ & 214 & $54.7 \%$ \\
\hline Clinical instructors & 101 & $69.7 \%$ & 107 & $66.8 \%$ & 59 & $70.2 \%$ & 267 & $68.2 \%$ \\
\hline classmate & 78 & $53 \%$ & 84 & $52.5 \%$ & 48 & $57.1 \%$ & 210 & $53.7 \%$ \\
\hline Physician & 58 & $39.5 \%$ & 71 & $44.4 \%$ & 39 & $46.4 \%$ & 168 & $42.9 \%$ \\
\hline Patients/family member & 53 & $36 \%$ & 70 & $43.7 \%$ & 39 & $46.4 \%$ & 162 & $41.4 \%$ \\
\hline Other hospital staff & 37 & $25.1 \%$ & 48 & $30 \%$ & 29 & $34.5 \%$ & 114 & $29.1 \%$ \\
\hline
\end{tabular}

*More than one answer was provided

Table (6): Distribution self esteem of bullied nursing students by academic semesters

\begin{tabular}{|c|c|c|c|c|c|c|c|c|c|c|}
\hline \multirow{3}{*}{ Levels of self esteem } & \multicolumn{8}{|c|}{ Semesters } & \multirow{3}{*}{$\begin{array}{c}\text { Test of } \\
\text { Sig. }\end{array}$} & \multirow{3}{*}{$\mathbf{P}$} \\
\hline & \multicolumn{2}{|c|}{$\begin{array}{c}\left(3^{\text {rd }}-4^{\text {th }}\right) \\
(n=147)\end{array}$} & \multicolumn{2}{|c|}{$\begin{array}{c}\left(5^{\text {th }}-6^{\text {th }}\right) \\
(n=160)\end{array}$} & \multicolumn{2}{|c|}{$\begin{array}{l}\left(7^{\text {th }}-8^{\text {th }}\right) \\
(n=84)\end{array}$} & \multicolumn{2}{|c|}{$\begin{array}{c}\text { Total } \\
\mathbf{n}=391\end{array}$} & & \\
\hline & No & $\%$ & No & $\%$ & No & $\%$ & No & $\%$ & & \\
\hline $\begin{array}{l}\text { Self esteem } \\
\text { low } \\
\text { moderate } \\
\text { high }\end{array}$ & $\begin{array}{l}19 \\
93 \\
35\end{array}$ & $\begin{array}{l}12.9 \% \\
63.3 \% \\
23.8 \%\end{array}$ & $\begin{array}{l}26 \\
89 \\
45\end{array}$ & $\begin{array}{l}16.3 \% \\
55.6 \% \\
28.1 \%\end{array}$ & $\begin{array}{l}18 \\
45 \\
21\end{array}$ & $\begin{array}{l}21.4 \% \\
53.6 \% \\
25.0 \%\end{array}$ & $\begin{array}{c}63 \\
227 \\
101\end{array}$ & $\begin{array}{l}16.1 \% \\
58.1 \% \\
25.8 \%\end{array}$ & $\begin{array}{c}\chi^{2}= \\
4.124\end{array}$ & 0.389 \\
\hline \begin{tabular}{|l} 
Total score \\
Min. -Max. \\
Mean \pm SD \\
\end{tabular} & \multicolumn{2}{|c|}{$\begin{array}{c}17.0-37.0 \\
29.36 \pm 4.13\end{array}$} & \multicolumn{2}{|c|}{$\begin{array}{c}18.0-39.0 \\
29.03 \pm 4.65\end{array}$} & \multicolumn{2}{|c|}{$\begin{array}{c}17.0-36.0 \\
28.74 \pm 4.69\end{array}$} & \multicolumn{2}{|c|}{$\begin{array}{c}17.0-39.0 \\
29.09 \pm 4.47\end{array}$} & $\begin{array}{c}\mathrm{F}= \\
0.543\end{array}$ & 0.582 \\
\hline $\begin{array}{l}\text { Percent score } \\
\text { Min. -Max. } \\
\text { Mean } \pm \text { SD } \\
\end{array}$ & \multicolumn{2}{|c|}{$\begin{array}{c}23.33-90.0 \\
64.54 \pm 13.77\end{array}$} & \multicolumn{2}{|c|}{$\begin{array}{l}26.67-96.67 \\
63.44 \pm 15.51\end{array}$} & \multicolumn{2}{|c|}{$\begin{array}{l}23.33-86.67 \\
62.46 \pm 15.64\end{array}$} & \multicolumn{2}{|c|}{$\begin{array}{l}13.10-100.0 \\
47.94 \pm 14.43\end{array}$} & $\begin{array}{c}\mathrm{F}= \\
0.543\end{array}$ & 0.582 \\
\hline
\end{tabular}


Table (7): The relationship between level of bullying behavior and type of coping strategies

\begin{tabular}{|c|c|c|c|c|c|c|c|c|c|c|}
\hline \multirow{3}{*}{ Coping strategies } & \multicolumn{6}{|c|}{ Bullying } & \multirow{3}{*}{\multicolumn{2}{|c|}{$\begin{array}{c}\text { Total } \\
\text { 391 } \\
\text { No \% }\end{array}$}} & \multirow{3}{*}{$\chi^{2}$} & \multirow{3}{*}{$\mathbf{P}$} \\
\hline & \multicolumn{2}{|c|}{$\begin{array}{c}\text { low } \\
(\mathrm{n}=354)\end{array}$} & \multicolumn{2}{|c|}{$\begin{array}{c}\text { moderate } \\
(n=35)\end{array}$} & \multicolumn{2}{|c|}{$\begin{array}{c}\text { high } \\
(\mathrm{n}=2)\end{array}$} & & & & \\
\hline & No & $\%$ & No & $\%$ & No & $\%$ & & & & \\
\hline Self-distraction & 65 & 18.3 & 9 & 25.7 & 1 & 50 & 75 & 19.2 & 1.685 & 0.414 \\
\hline Active coping & 8 & 2.3 & 3 & 8.6 & 1 & 50 & 12 & 3.1 & 6.387 & 0.055 \\
\hline Denial & 78 & 22 & 8 & 22.8 & 2 & 100 & 88 & 22.5 & $4.353^{*}$ & 0.049 \\
\hline Substance abuse & 11 & 3.1 & 3 & 8.6 & 1 & 50 & 15 & 3.8 & 6.636 & 0.083 \\
\hline Use of emotional support & 60 & 17 & 7 & 20 & 1 & 50 & 68 & 17.4 & 1.818 & 0.349 \\
\hline $\begin{array}{l}\text { Use of instrumental } \\
\text { support }\end{array}$ & 88 & 24.8 & 10 & 28.6 & 2 & 100 & 100 & 25.5 & 3.767 & 0.064 \\
\hline Behavior disengagement & 16 & 4.5 & 4 & 11.4 & 1 & 50 & 21 & 5.4 & 4.800 & 0.157 \\
\hline Venting & 97 & 27.4 & 15 & 42.8 & 1 & 50 & 113 & 28.9 & 1.034 & 1.000 \\
\hline Positive reframing & 106 & 29.9 & 13 & 37.1 & 2 & 100 & 121 & 30.9 & 2.951 & 0.096 \\
\hline Planning & 83 & 23.4 & 25 & 71.4 & 1 & 50 & 109 & 27.9 & 1.028 & 1.000 \\
\hline Humor & 51 & 14.4 & 4 & 11.4 & 1 & 50 & 56 & 14.3 & 2.255 & 0.302 \\
\hline Acceptance & 60 & 16.9 & 8 & 22.8 & 1 & 50 & 69 & 17.6 & 2.172 & 0.465 \\
\hline Religion & 155 & 43.8 & 27 & 77.1 & 2 & 100 & 184 & 47.0 & 1.425 & 0.696 \\
\hline Self-blame & 71 & 20 & 6 & 17.1 & 1 & 50 & 78 & 19.9 & 1.622 & 0.429 \\
\hline
\end{tabular}

$\chi^{2}, p: \chi^{2}$ and $p$ values for Chi square test

MC: Monte Carlo for Chi square test

*: Statistically significant at $p \leq 0.05$

Table (8): Correlation between bullying behaviors, coping strategies, and self esteem, among studied nursing students

\begin{tabular}{|c|c|c|c|c|}
\hline & & Bullying & Coping & Self esteem \\
\hline \multirow{2}{*}{ Bullying } & $\mathbf{r}$ & & & \\
\hline & $\mathbf{P}$ & & & \\
\hline \multirow{2}{*}{ Coping } & $\mathbf{r}$ & 0.053 & & \\
\hline & $\mathbf{P}$ & 0.297 & & \\
\hline \multirow{2}{*}{ Self esteem } & $\mathbf{r}$ & -0.003 & 0.094 & \\
\hline & $\mathbf{P}$ & 0.958 & 0.065 & \\
\hline
\end{tabular}

r: Pearson coefficient 


\section{References}

1. Clarke C, Kane D, Rajacich D, Lafreniere K. Bullying in Undergraduate Clinical Nursing Education. Journal of Nursing Education 2012; 51(5): 269-76.

2. Orpinas P, Horne A. Bullying prevention: creating a positive school climate and developing social competence. American Psychological Association, 2006. Available at: http://sur.ly/o/bookzz.org. Retrieved on: 9/ $21 / 2014$.

3. Stevenson K, Randle J, and Grayling I. Intergroup conflict in health care: UK students' experiences of bullying and the need for organizational solutions. Online Journal of Issues in Nursing 2006; 11(2): 5-6. Available at: http://gm6.nursingworld.org/. Retrieved on: 4/ 21/2015.

4. Kuehn B. Violence in health care settings on rise. Journal of the American Medical Association 2010; 304(5): 511-2.

5. Celik S, Bayraktar N. A study of nursing student abuse in Turkey. Journal of Nursing Education 2004; 43(7): 330-6.

6. Davey L. Nurses eating nurses: the caring profession which fails to nurture its own! Contemporary Nurse 2002; 13(2-3): 192-7.

7. Kassem A. Bullying behaviors and self efficacy among nursing students at clinical settings: comparative study. Journal of Education and Practice 2015; 6(35): 25-36.

8. Randle J. Bullying in the nursing profession. Journal of Advanced Nursing 2003; 43(4): 395401.

9. Clarke C. The effects of bullying behaviors on student nurses in the clinical setting.Master of Science at the University of Windsor. Electronic Theses and Dissertations 2009. Available at: http://scholar.uwindsor.ca/. Retrieved on: 4/7/2015.

10. Farrell G. From tall poppies to squashed weeds: why don't nurses pull together more? Journal of Advanced Nursing 2001; 35(1): 26-33.

11. Kim S, Varjas K, Henrich C, and Meyers J. Measuring students' self-efficacy in bullying situations. Bullying at School and Online, 2nd ed. a special issue of Education. Available at: http://www education com. Retrieved on: 08/15/ 2016.

12. McKenna B, Smith N, Poole S, and Coverdale J. Horizontal violence: experiences of registered nurses in their first year of practice. Journal of Advanced Nursing 2003; 42(1): 90-6.

13. Brockner J. Self-esteem at work: research, theory, and practice. Lexington Books/DC Heath and Com, 1988. Available at: http://www.amazon.com/ Retrieved on: 3/ $10 / 2015$.

14. Randle J. The effect of a 3-year pre-registration training course on students' self-esteem. Journal of Clinical Nursing 2001; 10(2): 293-300.

15. Matthieu M, Ivanoff A. Using stress, appraisal, and coping theories in clinical practice: assessments of coping strategies after disasters. Brief Treatment and Crisis Intervention 2006; 6(4): 337-48.

16. Mabrouk R. Perception of student nurses' bullying behaviors and coping strategies used in clinical settings. Available at: http://www.nursinglibrary.org/vhl/handle/10755 1316820. Retrieved on: 03/22/17.

17. Celik S, Bayraktar N. A study of nursing student abuse in Turkey. Journal of Nursing Education 2004; 43(7): 330-6.

18. Foster B, Mackie B, and Barnett N. Bullying in the health sector: A study of bullying of nursing students. New Zealand Journal of Employment Relations 2004; 29(2): 67-83.

19. Cooper J, Walker J, Askew R, Robinson J,and McNair M. Students' perceptions of bullying behaviors by nursing faculty. Issues in Educational Research 2011; 21(1):1-21.

20. Sable M. Danis F, Mauzy, D. and Gallagher S. Barriers to reporting sexual assault for women and men: $\mathrm{P}$ perspectives of college students. Journal of American College Health 2006; 55(3): 157-162.

21. Salin D. The prevention of workplace bullying as a question of human resource management: measures adopted and underlying organizational factors. Scandinavian Journal of Management 2008; 24(3): 221-31.

22. Bray C. Bullying nurses at work: theorizing a gendered experience. Contemporary Nurse 2001; 10(1-2): 21-9.

23. Celik S, Bayraktar N. A study of nursing student abuse in Turkey. Journal of Nursing Education 2004; 43(7): 330-6.

24. Magnussen L, Amundson M. Undergraduate nursing student experience. Nursing and Health Sciences 2003; 5, 261-267.

25. Basal A, Elhossiny E. Nursing Students' Perception and Experience of Bullying Behavior in the Faculty of Nursing. Nature and Science 2014; 12(1): 20-27.

26. Albakoor F. The relationship between the educational environment and nursing students' self esteem. Unpublished Master Thesis. Faculty of Nursing: Alexandria University, Egypt, 2008.

27. Folkman S, Lazarus R. If it changes it must be a process: A study of emotion and coping during three stages of a college examination. Journal of Personality and Social Psychology 1985; 48(1): 150-170.

28. Sharp S. 1995. How much does bullying hurt? The effects of bullying on the personal well being and educational progress of secondary aged students. Educ Child Psychol 12:81-8. 